\title{
The Effectiveness of Entrepreneurial Motivational Training Programme among University Students
}

\author{
Zarina Abdul Munir, Syukuriah Idrus, Shamsul Azren Mohd Shukur, Rahimah Ithnin, and Siti Sarah \\ Mohamad
}

\begin{abstract}
Entrepreneurial Development makes a powerful impact on the development of the country. The success of the entrepreneur depends on the environmental factors such as economic, legal, social, political and technological factors which influence the motivational factors thus leading to successful entrepreneurship. The motivational factors are the key factors influencing the entrepreneurial behavior and operation of the business and thus the need for the study on the entrepreneurial behavior and their due influence. The aim of this paper is through a quantitative study to determine how efficient academic entrepreneurship motivation training occurs in an academic environment and how these programmed are structured and organized. Major implications of this study are to address clear motivational training objectives and to base the content of programs on specific characteristics of the local or regional environment. It is also important $(i)$ to improve the entrepreneurship skills of students and other potential participants might shed light on how motivational training method could be improved, and (ii) to set up a networking group to facilitate creation of the entrepreneurship process.
\end{abstract}

Index Terms-Entrepreneurial motivation, training programs, entrepreneurship.

\section{INTRODUCTION}

An entrepreneur is a businessperson who not only conceives and organizes ventures but also frequently takes risks in doing so. Not all independent business people are true entrepreneurs, and not all entrepreneurs are created equal. That is the reason why entrepreneur must attend entrepreneurial motivational training programmed to become successful entrepreneur in the future.

Higher institutions, government agencies and private corporations have setting up programmed, trainings, seminars, events and funds in producing dynamic entrepreneurs. By attending these programmed, it will lead to students to be an entrepreneur, stimulate university students into becoming business owners and explore the motivation behind university students into becoming business owners. Some people tend to be their own boss in the firm. So, most of university students attend these course in order to gain knowledge and improve their entrepreneurial skills.

Entrepreneurship education seeks to provide students with the knowledge, skills and motivation to encourage entrepreneurial success in a variety of settings. Variations of

Manuscript received January 10, 2014; revised March 13, 2014.

Zarina Abdul Munir, Syukuriah Idrus, Shamsul Azren Mohd Shukur, and Siti Sarah Mohamad are with the Faculty of Business Management, University Teknologi Mara, Malaysia (e-mail: sshukur2001@yahoo.com).

Rahimah Ithnin is with Ministry of Communication and Multimedia Malaysia. entrepreneurship education are offered at all levels of schooling from primary or secondary schools through graduate university programs. Entrepreneurship education seeks to provide students with the knowledge, skills and motivation to encourage entrepreneurial success in a variety of settings. Variations of entrepreneurship education are offered at all levels of schooling from primary or secondary schools through graduate university programs.

In Malaysia, a lot of entrepreneurial motivational training programmed introduced by higher institutions. Students can grab this opportunities to enhance their entrepreneurial skills and knowledge. Sometimes people are tends to argues, is this entrepreneurial motivational training programmed really successful implement in our country especially in higher institutions itself.

Some sort of these questions is driven to come out with this kind of papers. This paper examines the effectiveness of academic entrepreneurship motivation training occurs in an academic environment. Besides that, this paper also determines how the entrepreneurial motivational training programmed are structured and organized. The efficiency of entrepreneurial training programs was determined on Contents, Delivery, Benefit and Entrants Quality. In this paper, it is important to address clear motivational training objectives and to base the content of programs on specific characteristics of the local or regional environment.

\section{LITERATURE REVIEW}

Motivation to become entrepreneur comes from various sources. Usually people tends to become self owner and be own boss in the business area have high motivation to become entrepreneur. High motivation also relates to having high self esteem in individual aspects. This is because, high self esteem people tends to drives to take on the risk, the uncertainty and the independent structure of business ownership successfully. Previous researchers mentioned several reasons and causes in individual aspects relates to motivation to become entrepreneur.

Segal et al. [1] mentioned that being an entrepreneur is often viewed as an aversive career choice where one is faced with everyday life and work situations that are fraught with increased uncertainty, impediments, failures, and frustrations associated with the process of new firm creation. Entrepreneurship research has also attempted to identify the situational and environmental factors that predict entrepreneurial activity, such as job displacement, previous work experience, availability of various resources, and governmental influences. 
Motivation is conceptualized as the product of expectancy, instrumentality, and valence [1]. Expectancy is resulting to measures such as perceived feasibility and self-efficacy used in other models predicting entrepreneurial intentions to become own boss. Praag and Cramer [2] found that people would become entrepreneurs if the expected rewards surpass the wages of employment. Expected rewards depended on assessments of individual ability and attitudes towards risk, perceptions of entrepreneurial feasibility were included [1].

Some researchers prefer that variance of earnings for self-employed individuals was triple that of individuals working for others, leading to the conclusion that risk-averse individuals are less likely to pursue self-employment. People may be motivated to become entrepreneurs if they believe self-employment is more likely than working for others to lead to valued outcomes. The motivation to become an entrepreneur is driven by the difference between the desirability of self-employment and the desirability of working for others included [1].

However, Segal et al. [1] also mentioned that not all people viewing themselves as effective, and seeing self-employment as a path to acquiring desirable outcomes, intend to become self-employed. To act on the perceptions of feasibility and net desirability, people must be willing to bear the moderate, calculated risk intrinsic to self-employment. People with a sense of entrepreneurial self-efficacy may be drawn to self-employment's desirable opportunities and benefits, compared to the availability of these benefits obtained through working for others. Segal et al [1] stressed that the intention to become an entrepreneur is a function of these three variables: the perceived net desirability of self-employment (NDSE), the perceived feasibility (self-efficacy) of self-employment (SE), and tolerance for risk (TR).

Segal et al. [1] stated the usefulness of the perceived desirability of self-employment on the intention to engage in entrepreneurial activity. Besides that, individual's tolerance for risk (TR) had a significant influence on his or her intention to engage in entrepreneurial activity. It was also important that person have a relatively high tolerance for risk to engage in such activity.

Munro and Cook [3] mentioned that one of the key criticisms of the Honey and Mumford approach is that thinking is treated as concluding not starting. In this model, which revises the Kolb and Honey and Mumford Models, it is suggested that the environment of the learner is integral to the development of the learner. This has formed the basis for a model, which outlines the three dimensions of enterprise in the forms of envisioning, energizing, and expediting. The key elements of students initially working in teams widens the immediate networks on which they can draw and with the mix in the team they can gain a synergy of vision, energy and expediting. This revision of Kolb's learning cycle is challenging and engaging and makes the participants more fitted for the small and general business environment on graduation.

Kirby [4] was argues that the traditional education system stultifies rather than develops the requisite attributes and skills to produce entrepreneurs. His proposes that if entrepreneurs are to be developed, considerable changes are required in both the content and process of learning. According to [4] also suggests that there needs to be a shift in the emphasis from educating "about" entrepreneurship to educating "for" it.

Many individuals are entering self-employment such as creating a business as a means of escaping the unstable nature of the new work environment [5]. This indicates the result with an increasingly diverse self-employed population that includes growing numbers of youths who are choosing to create a job by creating a business on their own. According to Kirby [4] experience is the most important elements in motivate them to open business because experience had influenced their choices in participating business industry.

People can specify what age they feel they would like obviously be capable to start a business indicates an awareness of their own self-efficacy and ideas for enterprise opportunities. Self efficacy has been found to be significantly related to stated occupational interest and choices [4]. The contribution of experiential learning and self-employment to entrepreneurial self-efficacy is supported by numerous research findings that have shown that entrepreneurs tend to have parents who are also self-employed [4]. Data on student career aspirations from other country showed that the respondents whose parents were self-employed full time showed the highest preference for self-employment [4]. It means that the motivation to become entrepreneur also indicates from their parents itself.

Matlay [6] stated that entrepreneurship education can increase both the quality and the quantity of graduate entrepreneurs entering the industry. Most of the initiatives were included a specific entrepreneurship agenda that sought to enhance entrepreneurial motivation and business competency amongst the expanding cohort of new graduates. Besides that, it was also stressed that the propensity of graduates to become growing entrepreneurs is influenced by existing socio-economic and educational conditions that are specific to the country and its position in the global economy.

Galloway et al. [7] examine the potential of entrepreneurship education to develop skills, and of whether students perceive them as having value within the modern economy. The results also suggest that many students expect to work in new and small firms, and that skills developed by entrepreneurship education are applicable to both waged employment and entrepreneurship [7]. According to him [7] entrepreneurship education seems to have much potential to develop skills appropriate for the enterprise economy.

Students perceive that entrepreneurship education has improved their entrepreneurial skills, and the greater proportion of students believe that skills learnt and developed by entrepreneurship education are applicable and important to non-self-employment or business ownership occupations. Traditionally, entrepreneurship researchers have studied the factors that motivate someone to start an entrepreneurial career rather than focusing on career progression and advancement.

Henderson and Robertson [8] show that education has important roles in providing challenges in being an entrepreneur and also encouraging skill development and self-sufficiency. Young generations must have sufficient knowledge of small firms and entrepreneurship as a chosen 
career. Studying a higher education could have influenced their choices in business venture startup [8]. So, it will relate to the motivation to become entrepreneur in the future.

\section{Methodology}

The study utilized a descriptive research design. The sample comprised of 1,554 university students from three research universities in Malaysia. Data were gathered in March 2010 using a set of questionnaire measuring students' background information and entrepreneurial intention.

The instrument was developed based on the modification of previous instruments developed by several. The reliability of each set of constructs has a Cronbach $\alpha$ value ranged between .776 and .809 (see Table I-Table III).

TABLE I: RELIABILITY STATISTICS-PRO ACTIVENESS

\begin{tabular}{|c|c|}
\hline Cronbach's Alpha & $N$ of Items \\
\hline 0.809 & 12 \\
\hline
\end{tabular}

TABLE II: RELIABILITY STATISTICS-RISK TAKING

\begin{tabular}{|c|c|}
\hline Cronbach's Alpha & $N$ of Items \\
\hline 0.776 & 7 \\
\hline
\end{tabular}

TABLE III: RELIABILITY STATISTICS-INNOVATIVENESS

\begin{tabular}{|c|c|}
\hline Cronbach's Alpha & $N$ of Items \\
\hline 0.780 & 6 \\
\hline
\end{tabular}

The measurement of items in the survey questionnaire was based on 5 point Likert scales with 1 demonstrating "strongly disagree" to 5 demonstrating "strongly agree". Negatively worded items were rescored so that higher scores reflected its mean. Mean score above 3.80 is considered high, 3.40-3.79 considered moderate and below 3.39 considered as low perceptions. Data were analyzed using descriptive and inferential statistics.

\section{FINDINGS}

Table IV illustrates that in general students perceived moderately on all items measuring entrepreneurial intention with the exception of item 12, that is "I want to be my own boss" (mean=4.01, s.d=0.77). The least mean score is for these items as "I have some capital to invest." (mean=2.95, $\mathrm{s.d}=1.12$ ) and "I do not see why I would start at zero." (mean 3.00, s.d.=1.04).

Table $\mathrm{V}$ illustrates that in general students perceived moderately on all items measuring risk taking with the exception of item 7, that is "This company needs to grow and I can help it reach its potential." (mean=3.65, s.d=0.91). The least mean score is for these items as "There is no job that corresponds to what I would like to do." (mean=2.95, $\mathrm{s.d}=1.12$ ).

Table VI illustrates that in general students perceived moderately on all items measuring innovativeness with the exception of item 6 that is "I would like to leave a nice inheritance to my children." (mean=4.19, s.d=0.83) and "I am ready to work hard." (mean $=4.15$, s.d=0.81). The least mean score is for these items as "Other reasons." (mean=2.94, s.d=1.06).

TABLE IV: DESCRIPTIVE STATISTICS ON ENTREPRENEURIAL INTENTION

\begin{tabular}{|c|c|c|c|}
\hline \multicolumn{4}{|c|}{ Descriptive Statistics } \\
\hline & $N$ & Mean & $\begin{array}{c}\text { Std. } \\
\text { Deviation } \\
\end{array}$ \\
\hline & Statistic & Statistic & Statistic \\
\hline I want to be my own boss. & 108 & 4.102 & 0.773 \\
\hline $\begin{array}{l}\text { I like to have elbow room and to be } \\
\text { autonomous. }\end{array}$ & 108 & 3.796 & 0.862 \\
\hline $\begin{array}{l}\text { I am a determined person and I am } \\
\text { adventurous. }\end{array}$ & 108 & 3.954 & 0.647 \\
\hline $\begin{array}{l}\text { I see it as a way to realize my full } \\
\text { potential. }\end{array}$ & 108 & 3.843 & 0.751 \\
\hline $\begin{array}{l}\text { I have always dreamed of having my } \\
\text { own business. }\end{array}$ & 108 & 4.046 & 0.802 \\
\hline $\begin{array}{l}\text { I want to create something of my } \\
\text { own. }\end{array}$ & 108 & 4.065 & 0.789 \\
\hline I have some capital to invest. & 108 & 2.954 & 1.122 \\
\hline $\begin{array}{l}\text { I would like to work hard, make some } \\
\text { money, and reap the rewards. }\end{array}$ & 108 & 4.139 & 0.803 \\
\hline I do not see why I would start at zero. & 108 & 3.009 & 1.046 \\
\hline $\begin{array}{l}\text { I prefer to build on something } \\
\text { existing than to create something } \\
\text { from scratch. }\end{array}$ & 108 & 3.426 & 0.909 \\
\hline $\begin{array}{l}\text { I see it as an opportunity to make a } \\
\text { name for myself. }\end{array}$ & 108 & 3.889 & 0.777 \\
\hline $\begin{array}{l}\text { I have experience working in a team } \\
\text { and I would like to create my own } \\
\text { team. }\end{array}$ & 108 & 3.759 & 0.946 \\
\hline Valid $N$ (listwise) & 108 & & \\
\hline
\end{tabular}

TABLE V: DESCRIPTIVE STATISTICS ON RISK TAKING

\begin{tabular}{|l|c|c|c|}
\hline \multicolumn{4}{|c|}{ Descriptive Statistics } \\
\hline & $N$ & Mean & SD \\
\hline $\begin{array}{l}\text { I have skills and professional } \\
\text { know-how that are clearly } \\
\text { under-utilized in my current situation. }\end{array}$ & 108 & Statistic & Statistic \\
\hline $\begin{array}{l}\text { I am at the right age and the conditions } \\
\text { are right for a career change. }\end{array}$ & 108 & 3.611 & 0.755 \\
\hline $\begin{array}{l}\text { There is no job that corresponds to what } \\
\text { I would like to do. }\end{array}$ & 108 & 3.278 & 0.806 \\
\hline $\begin{array}{l}\text { This company needs to grow and I can } \\
\text { help it reach its potential. }\end{array}$ & 108 & 3.648 & 0.910 \\
\hline $\begin{array}{l}\text { I do not have a job and I decided to take } \\
\text { the risk. }\end{array}$ & 108 & 3.380 & 0.993 \\
\hline $\begin{array}{l}\text { I would like to keep these jobs in my } \\
\text { region. }\end{array}$ & 108 & 3.639 & 0.891 \\
\hline $\begin{array}{l}\text { I want to grow this company, and then } \\
\text { sell it at a good price as a way to build a } \\
\text { comfortable retirement. }\end{array}$ & 108 & 3.556 & 1.035 \\
\hline Valid $N$ (listwise) & 108 & & \\
\hline
\end{tabular}

TABLE VI: DESCRIPTIVE STATISTICS ON INNOVATIVENESS

\begin{tabular}{|l|c|c|c|}
\hline \multicolumn{4}{|c|}{ Descriptive Statistics } \\
\hline & $\mathrm{N}$ & Mean & SD \\
\hline & Statistic & Statistic & Statistic \\
\hline $\begin{array}{l}\text { I would like to leave a nice } \\
\text { inheritance to my children. }\end{array}$ & 108 & 4.185 & 0.833 \\
\hline I am ready to work hard. & 108 & 4.148 & 0.807 \\
\hline $\begin{array}{l}\text { I can gather, analyze, and } \\
\text { synthesize information into } \\
\text { something solid on which I } \\
\text { can base my decisions. }\end{array}$ & 108 & 3.741 & 0.790 \\
\hline I am not afraid of risk. & 108 & 3.732 & 0.781 \\
\hline I can manage my stress. & 108 & 3.796 & 0.746 \\
\hline Other reasons & 108 & 2.944 & 1.058 \\
\hline Valid $N$ (listwise) & 108 & & \\
\hline
\end{tabular}




\section{CONCLUSIONS AND IMPLICATIONS}

This work substantially expands the understanding of what drives the intention of university students to become an entrepreneur. It helps to understand the importance of entrepreneurial exposure in term of management, finance and marketing competencies as a basis to choose entrepreneurship as a career choice.

University students participated in this study has moderate entrepreneurial intention. Since, the intention to start one's own business appears to be driven by "more entrepreneurial" attitudes towards entrepreneurial career. University policy makers and educators might encourage self-employment by facilitating the development of more entrepreneurial intention, attitudes and entrepreneurial self-efficacy in the aspects of management, financial and marketing. University should add more value to their graduates if they incorporate into their curriculum elements that enhance the development of entrepreneurial attitudes and self-efficacy, since these are beneficial to both a self-employment and employment career path.

\section{REFERENCES}

[1] G. Segal, D. Borgia and J. Schoenfeld, "The motivation to become an entrepreneur," International Journal of Entrepreneurial Behaviour and Research, vol. 11, no. 1, pp. 42-57, 2005.
[2] C. M. Praag and J. S. Cramer, "The roots of entrepreneurship and labor demand: individual ability and low risk," Economica, vol. 68, no. 269 , pp. 45-62, 2001.

[3] J. Munro and R. Cook, "The small enterprise as the authentic learning environment opportunity (SEALEO)," Aslib Proceedings: New Information Perspectives, vol. 60, no. 6, pp. 686-700, 2008.

[4] D. A. Kirby, "Points of view Entrepreneurship education: can business schools meet the challenge?" Journal of Education and Training, vol. 46, no. 8-9, pp. 510-519, 2004.

[5] K. Lewis, "The best of intentions: future plans of young enterprise scheme participants," Journal of Education and Training, vol. 47, no. 7, pp. 470-483, 2005.

[6] H. Matlay, "Researching entrepreneurship and education: what is entrepreneurship education and does it matter?" Journal of Education and Training, vol. 48, no. 8-9, pp. 704-718, 2006.

[7] L. Galloway, M. Anderson, W. Brown, and L. Wilson, "Enterprise skills for the economy," Journal of Education and Training, vol. 47, no. 1, pp. 7-17, 2005.

[8] R. Henderson and M. Robertson, "Who wants to be an entrepreneur? Young adult attitudes to entrepreneurship as a career," Journal Education and Training, vol. 41, no. 5, pp. 236-245, 1999.

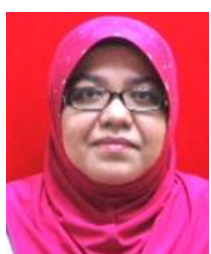

Zarina Abdul Munir is a senior lecturer at Universiti Teknologi Mara, Malaysia. Her area of interests include entrepreneurship, organizational behaviour and human resource development. 